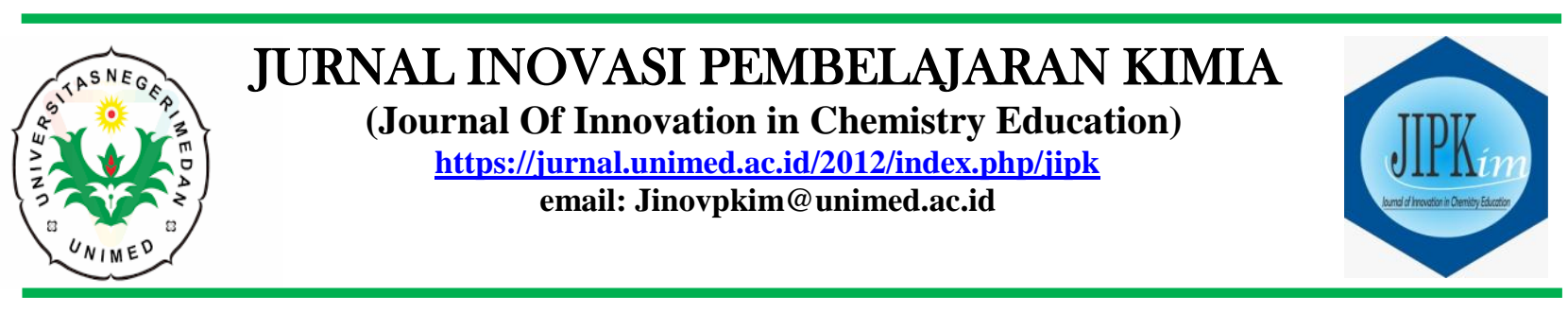

$\begin{array}{ll}\text { Masuk } & : \text { 7 Februari } 2021 \\ \text { Revisi } & : \text { 15 April } 2021 \\ \text { Diterima } & : \text { 20 April } 2021 \\ \text { Diterbitkan } & : \text { 20 April } 2021 \\ \text { Halaman } & : 22-34\end{array}$

\title{
Pengembangan LKPD Berorientasi STEM dengan Model PjBL Materi Larutan Elektrolit Nonelektrolit dengan Memanfaatkan Bahan Sekitar
}

\author{
Anisatul Ma'sumah', Mitarlis ${ }^{2 *}$ \\ ${ }^{1,2}$ Program Studi Pendidikan Kimia, Universitas Negeri Surabaya, Surabaya \\ *Alamat Korespondensi: mitarlis@unesa.ac.id
}

\begin{abstract}
The aim of this research is producing student worksheets STEM-oriented with PjBL model of electrolyte and non-electrolyte matter by utilizing surrounding materials. This study used 4-D development model (four-D model), which is a development model consisting of 4 main stages: Define, Design, Develop, and Disseminate. This research was limited to the develop stage and limited trials were carried out on 9 students of SMAN 1 Gedangan Sidoarjo. The feasibility of student worksheets is seen based on aspects of validity, practicality, and effectiveness. This research shows the results of the validity student worksheets on the content criteria as $85.84 \%$ and the construct validity of $86.56 \%$ on very good category. The results of students' responses to the student worksheets obtained a percentage of $96.67 \%$ on very practical category, observation of the first to the third meetings obtained an average percentage of $90.65 \%$ on very practical category. The results effectiveness of the student worksheets obtained an average $\mathrm{N}$-Gain score of 0.83 with a high category which proved that the learning outcomes of students have increased on the tests before and after learning to use student worksheets.
\end{abstract}

Keywords: Student Worksheets, STEM, PjBL, Surrounding materials

\section{PENDAHULUAN}

Pendidikan merupakan bidang yang cukup berpengaruh dalam proses menciptakan Sumber Daya Manusia (SDM) dengan kualitas tinggi. Pemerintah dalam menghadapi tantangan abad 21 telah menyiapkan beberapa program diantaranya 4C (Critical Thinking, Communiaction, Collaboration, Creativity) (Sugiyarti, dkk., 2018). Permendikbud Nomor 36 Tahun 2018: Tentang perubahan Permendikbud Nomor 59 Tahun 2014, kurikulum 2013 mengembangkan pengalaman belajar yang memberikan kesempatan luas bagi peserta didik untuk menguasai kompetensi yang diperlukan bagi kehidupan masa kini dan masa depan (Permendikbud, 2018).

Siswa abad-21 dituntut untuk dapat bersaing secara global dalam hal pengetahuan dan ketrampilan. Pertumbuhan ekonomi di abad ke-21 akan dipengaruhi oleh kemampuan untuk menghasilkan ide dan menerjemahkannya ke dalam produk serta layanan yang inovatif. Menaikkan tingkat kelulusan sekolah menengah dan memastikan semua siswa siap untuk kuliah dan menjadi tenaga kerja bagi suatu negara untuk bersaing dalam ekonomi global 
(OECD, 2018). Penelitian sebelumnya menerangkan bahwa keahlian yang dibutuhkan dalam dunia usaha pada abad 21 yaitu ketrampilan belajar berinovasi, kehidupan karir, serta ketrampilan dalam teknologi dan media informasi (Wijaya, dkk., 2016).

Pusat Penelitian Pendidikan menunjukkan hasil nilai UN SMA/MA IPA, nilai rata-rata termasuk mata pelajaran kimia berada dibawah nilai minimum kelulusan yang telah ditetapkan Kemendikbud yaitu 55,00. Nilai rata-rata UN SMA (IPA) tahun pelajaran 2019 mata pelajaran kimia adalah 50,99 sedangkan untuk nilai UN MA (IPA) tahun pelajan 2019 mata pelajaran kimia adalah 46,73 (Kemendikbud, 2019). Kimia adalah salah satu ilmu yang tergolong sulit dalam hal pemahamannya karena beberapa konsep dalam ilmu kimia bersifat abstrak. Larutan elektrolit merupakan materi pembelajaran kimia yang menuntut peserta didik melakukan percobaan dalam pengujian larutan untuk memahami konsep dari materi tersebut.

Pembelajaran pada masa pandemi Covid-19 berdasarkan Surat Keputusan Bersama Empat Menteri tentang Panduan Penyelenggaraan Pembelajaran pada Tahun Ajaran 2020/2021 di Masa Pandemi Covid19 dilarang melakukan pembelajaran tatapmuka dan dilakukan secara metode daring (belajar di rumah) terutama pada sekolah-sekolah pada zona orange dan zona merah (SKB Empat Menteri, 2020). Metode pembelajaran daring sangat berpengaruh terhadap keefektivan kegiatan belajar mengajar utamanya pada pembelajaran yang membutuhkan praktikum dalam memahami konsep materinya. Farida, dkk. (2020) dalam penelitiannya pembelajaran kimia menggunakan sistem daring pada masa pandemi Covid-19 menunjukkan bahwa kimia dalam pemahamannya bukan hanya pemahaman mengenai teori saja tetapi juga pemahaman praktik. Kesulitan belajar sangat dirasakan dalam konten yang berkaitan dengan perhitungan, reaksi-reaksi serta aspek submikroskopik. Konsep kimia yang abstrak memiliki potensi terjadi pemahaman yang keliru ketika bimbingan, metode serta media yang digunakan tidak sesuai dengan gaya belajar. Berdasarkan angket yang telah disebar di SMAN 1 Gedangan Sidoarjo mengenai proses pembelajaran daring yang biasa dilakukan, $60 \%$ peserta menyatakan hanya diberikan materi serta latihan soal-soal saat pembelajaran kimia di masa pandemiCovid-19. Peserta didik juga menyatakan harapan pembelajaran kimia dimasa pandemi Covid-19 yaitu diharapkan dapat diberikan penjelasan materi disertai dengan praktikum jika memungkinkan dan dikaitkan dengan kehidupan nyata. Pemanfaatan bahan sekitar diharapkan dapat membantu peserta didik dalam melakukan praktikum di rumah masing-masing saat pembelajaran daring. Peserta didik akan lebih mudah memahami materi ketika dihubungkan dengan dunia nyata dengan memanfaatkan bahan sekitar sehingga tercipta pembelajaran yang efektif pada masa pandemi Covid-19.

Keberhasilan suatu pembelajaran tergantung model dan bahan ajar yang diterapkan oleh seorang guru pada proses pembelajaran di dalam kelas. LKS merupakan salah satu bahan ajar berisi tugastugas serta langkah kerjanya yang harus dikerjakan siswa sehingga siswa dapat belajar mandiri dengan bimbingan guru (Prastowo, 2011). Berdasarkan angket pra penelitian yang telah di sebar di SMAN 1 Gedangan menunjukkan $91,4 \%$ siswa menjawab LKPD yang biasa digunakan pada pembelajaran kimia hanya berupa ringkasan materi serta latihan soal. LKPD dapat dipadukan dengan berbagai model pembelajaran dalam penyusunannya untuk menghasilkan kegiatan pembelajaran yang baik, seperti contoh model pembelajaran berdasar proyek.

Model pembelajaran berdasar proyek dalam penerapaannya merupakan pembelajaran yang berpotensi dalam memberikan peserta didik pengalaman kreativitas serta penerapan dalam kehidupan nyata (Na'imah, dkk., 2015). Berdasarkan angket pra penelitian yang telah di sebar di 
SMAN 1 Gedangan menunjukkan 91,4\% siswa sangat tertarik jika pembelajaran kimia dihubungkan dengan kehidupan sehari-hari dengan alasan lebih memudahkan dalam memahami materi. Chiang \& Lee (2016) dalam penelitiannya menunjukkan hasil bahwa pennggunaan model PjBL terdapat pengaruh positif untuk motivasi belajar siswa. Kegiatan pembelajaran berbasis proyek terdiri dari memulai dengan pertanyaan essensial, merancang dan membuat desain proyek, menyusun jadwal, membuat proyek nyata dengan pengawasan guru, menyusun laporan dan mempresentasikan produk, mengevaluasi serta merefleksi produk (Mitarlis, dkk., 2017).

Pembelajaran Scientific, Technology, Enginering, and Mathematic (STEM) merupakan pembelajaran yang disarankan untuk membantu kesuksesan ketrampilan abad ke-21, yang merupakan perpaduan dari pembelajaran sains, teknologi, teknik, dan matematika (Larson \& Miller, 2011). STEM merupakan pendekatan pembelajaran yang dapat menciptakan kesiapan peserta didik untuk dapat bersaing dalam menghadapi tantangan dunia kerja abad-21. Hasil penelitian Jauhariyah, dkk., (2017) menunjukkan bahwa kemampuan serta bakat siswa untuk menghadapi abad-21 dapat dilatihkan menggunakan pembelajaran STEM-PjBL. Pembelajaran menggunakan STEM-PjBL dapat menunjang karir di masa depan, meningkatkan literasi sains, memotivasi siswa, meningkatkan pemahaman materi, meningkatkan kemampuan berfikir kreatif, efektivitas, serta pembelajaran yang lebih bermakna. Pembelajaran dengan menghubungkan dengan permasalahan pada dunia nyata akan menghasilkan pembelajaran yang lebih bermakna. Roehrig, dkk. (2021) dalam penelitiannya menyebutkan permasalahan pada dunia nyata merupakan komponen yang sangat penting dalam pembelajaran STEM terintregasi. Pembelajaran akan lebih bermakna ketika peserta didik dapat menciptakan hubungan antara pengetahuan yang telah didapatkan dengan pengalaman serta keterampilan baru pada konteks dunia nyata.

Berdasarkan paparan tersebut, maka dalam penelitian bertujuan untuk menghasilkan LKPD berorientasi STEM dengan model PjBL materi larutan elektrolit dan non elektrolit dengan memanfaatkan bahan sekitar yang layak diaplikasikan dalam pembelajaran kimia yang baik.

\section{KAJIAN LITERATUR}

\section{Scientific, Technology, Enginering, and Mathematic (STEM)}

STEM merupakan pendekatan pembelajaran yang dapat menciptakan kesiapan peserta didik untuk dapat bersaing dalam menghadapi tantangan dunia kerja abad-21. Pembelajaran Scientific, Technology, Enginering, and Mathematic (STEM) merupakan pembelajaran yang disarankan untuk membantu kesuksesan ketrampilan abad ke-21, yang merupakan perpaduan dari pembelajaran sains, teknologi, teknik, dan matematika (Larson \& Miller, 2011).

\section{Project Based Learning (PjBL)}

Kegiatan pembelajaran berbasis proyek terdiri dari memulai dengan pertanyaan essensial, merancang dan membuat desain proyek, menyusun jadwal, membuat proyek nyata dengan pengawasan guru, menyusun laporan dan mempresentasikan produk, mengevaluasi serta merefleksi produk (Mitarlis, dkk., 2017). pembelajaran berdasar proyek dalam penerapaannya merupakan pembelajaran yang berpotensi dalam memberikan peserta didik pengalaman kreativitas serta penerapan dalam kehidupan nyata (Na'imah, dkk., 2015). 


\section{METODE}

Penelitian ini menggunakan jenis penelitian dan pengembangan (Research and Development) pada bidang pendidikan dalam bentuk pengembangan LKPD. Model pengembangan yang digunakan dalam penelitian ini adalah model pengembangan 4-D (four-D model) yaitu model pengembangan yang terdiri dari 4 tahap utama yaitu: Define (pendefinisian), Design (perancangan), Develop (pengembangan), dan Disseminate (penyebaran). Penilitian ini dilakukan atau dibatasi sampai tahap develop (pengembangan) (Ibrahim \& Wahyusukartingsih, 2014). LKPD dapat dikategorikan layak apabila dapat memenuhi aspek validitas, kepraktisan, dan keefektivan (hasil uji coba terbatas). Uji coba terbatas dilakukan dengan menggunakan peserta didik kelas X MIPA 5 SMAN 1 Gedangan Sidoarjo sebanyak 9 orang dengan kriteria pemilihan secara random sampling.

Metode pengumpulan data, yaitu validasi yang dilakukan oleh validator dua dosen Pendidikan Kimia UNESA serta satu guru kimia SMAN 1 Gedangan, angket respon peserta didik, observasi aktivitas peserta didik, serta tes peningkatan hasil belajar.

Analisis data kevalidan dapat diketahui melalui data hasil validitas LKPD dari validator kemudian dianalisis dengan menggunakan metode deskripsi kuantitatif dengan memberi gambaran penelitian tentang kelayakan LKPD berdasarkan perhitungan skala likert dengan kriteria penilaian kurang sekali dengan nilai 1 , kurang baik dengan nilai 2, cukup baik dengan nilai 3 , baik dengan nilai 4 , serta baik sekali dengan nilai 5 (Riduwan, 2016). Presentasi kelayakan selanjutnya dihitung menggunakan rumus berikut:

$$
\begin{gathered}
P(\%)=\frac{\text { jumlah skor hasil }}{\text { skor kriteria }} \\
\text { Presentase yang }
\end{gathered} \times 100 \%
$$
diinterpretasikan sesuai Tabel 1 berikut (Riduwan, 2016).
Tabel 1. Kategori Presentase Validasi

\begin{tabular}{cc}
\hline Presentase $(\%)$ & Kategori \\
\hline $0-20$ & Tidak Valid \\
$21-40$ & Kurang Valid \\
$41-60$ & Cukup Valid \\
$61-80$ & Valid \\
$80-100$ & Sangat Valid \\
\hline
\end{tabular}

LKPD dapat dikatakan layak jika hasil penilaian mencapai kategori valid $(61 \%-80 \%)$ atau sangat valid (81\%-100\%).

Analisis data kepraktisan dapat dilihat dari data angket respon serta data oservasi peserta didik. Data respon peserta didik dianalisis dengan cara deskriptif kuantitatif untuk menggambarkan respon peserta didik mengenai hasil penelitian pengembangan, didapatkan dengan menggunakan perhitungan skala Guttman seperti pada Tabel 2 (Riduwan, 2016).

Tabel 2. Kriteria Skala Guttman

\begin{tabular}{ccc}
\hline Jawaban & $\begin{array}{c}\text { Nilai Jawaban } \\
\text { Positif }\end{array}$ & $\begin{array}{c}\text { Nilai Jawaban } \\
\text { Negatif }\end{array}$ \\
\hline Ya & 1 & 0 \\
Tidak & 0 & 1 \\
\hline
\end{tabular}

Data analisis aktivitas peserta didik didapatkan dari lembar pengamatan aktivitas peserta didik selama proses pembelajaran dengan uji coba LKPD berorientasi STEM dengan model PjBL materi larutan elektrolit dan non elektrolit dengan memanfaatkan bahan sekitar. Analisis peserta didik digunakan sebagai data pendukung respon peserta didik. Dalam hal ini digunakan skala Guttman dengan dua kriteria keterlaksanaan yaitu ya dan tidak. Skor yang diperoleh dari data respon dan aktivitas selanjutnya dihitung presentasi kelayakannya menggunakan rumus berikut:

$$
P(\%)=\frac{\text { skor } \text { yang diperoleh }}{\text { Jumlah responden }} \times 100 \%
$$

Presentasi kelayakan selanjutnya diinterpresentasikan dalam kategori yang diadaptasi dari Riduwan (2016) dengan nilai (0\%-20\%) dikategorikan tidak praktis, nilai (21\%-40\%) dikategorikan kurang praktis, nilai (41\%-60\%) dikategorikan cukup praktis, nilai (61\%-80\%) dikategorikan praktis, serta nilai (81\%-100\%) 
dikategorikan sangat praktis. LKPD dikategorikan layak atau dapat mendukung pembelajaran jika hasil penilaian mencapai kategori praktis dengan nilai $61 \%-80 \%$ atau sangat praktis dengan nilai $81 \%-100 \%$.

Analisis data efektivitas dilakukan dengan uji coba LKPD yang telah dikembangkan pada sekitar 9 peserta didik, kemudian dilakukan tes (pre-test dan posttest) untuk menunjukkan peningkatan hasil belajar setelah uji coba LKPD. Nilai tes (pre test dan post test) dapat dihasilkan dari jumlah skor yang diperoleh dibagi dengan jumlah skor maksimal kemudian dikalikan 100. Peningkatan hasil belajar peserta didik akan diketahui dari nilai pre-test dan posttest kemudian dihitung serta dijelaskan dengan kriteria $n$-gain score. Berikut rumus untuk menentukan $n$-gain score:

$$
<\mathrm{g}>=\frac{\text { nilai post test }- \text { nilai pre test }}{\text { nilai maksimal }- \text { nilai pre test }}
$$

Kategori n-gain score dapat dilihat dalam Tabel 4 (Nani \& Kusumah, 2015).

Tabel 3. Pengelompokan kategori $N$-gain score

\begin{tabular}{cc}
\hline Nilai & Kategori \\
\hline $\mathrm{g}>0,7$ & Tinggi \\
$0,7 \geq \mathrm{g} \geq 0,3$ & Sedang \\
$\mathrm{g}<0,3$ & Rendah \\
\hline
\end{tabular}

LKPD dapat dinyatakan efektif serta layak apabila diperoleh nilai $n$-gain $\geq 0,3$ dengan kategori sedang atau tinggi.

\section{HASIL DAN PEMBAHASAN}

Penelitian pengembangan ini bertujuan menghasilkan LKPD berorientasi STEM dengan model PjBL pada materi Larutan Elektrolit dan Non Elektrolit dengan memanfaatkan bahan sekitar yang layak digunakan. Penelitian ini menggunakan model pengembangan 4-D ( Define, Desain, Develop, Disseminate) tetapi dibatasi sampai tahapan Develop (Ibrahim \& Wahyusukartingsih, 2014). Berikut pembahasan mengenai tahapan-tahapan yang telah dilalui dalam penelitian pengembangan ini.

\section{Tahap Define (Pendefinisian)}

Tahap pertama yaitu tahapan pendefinisian. Aspek-aspek yang dianalisis dari tahapan ini yaitu analisis kompetensi, kemampuan peserta didik, tugas, konsep, serta perumusan tujuan pembelajaran (Ibrahim \& Wahyusukartingsih, 2014).

Analisis kompetensi dilakukan dengan mempertimbangkan kurikulum 2013, dimana merupakan kurikulum yang sedang berlaku saat ini. Analisis peserta didik berupa menggali kemampuan serta pengalaman belajar peserta didik sebelumnya. Analisis tugas dilakukan dengan menyesuaikan isi LKPD dengan KI, KD kemudian disesuaikan dengan kurikulum yang sedang berlaku dengan tujuan untuk mencapai kompetensi. Analisis konsep dalam penelitian ini dilakukan dengan cara memilih konsep pokok terlebih dahulu kemudian menyusun kembali dengan cara yang terstruktur dan terperinci. Penelitian ini menggunakan materi pokok larutan elektrolit dan non elektrolit. Perumusan tujuan pembelajaran dilakukan untuk mengetahui tujuan dari pembelajaran yang ingin dicapai pada LKPD yang akan dikembangkan.

\section{Tahap Design (Perancangan)}

Tahap kedua yaitu tahapan perangcangan. Tahapan perangcangan ini dilakukan untuk menyusun komponenkomponen yang akan diaplikasikan pada LKPD. LKPD ini mencantumkan aspekaspek Science, Technology, Engineering, and Mathematic (STEM). LKPD ini juga mencantumkan beberapa tahapan model Project Based Learning (PjBL) berupa memulai dengan pertanyaan essensial, merancang dan membuat desain proyek, menyusun jadwal, membuat proyek nyata dengan pengawasan guru, menyusun laporan dan mempresentasikan produk, mengevaluasi serta merefleksi produk (Mitarlis, dkk., 2017). Hasil dari tahapan perancangan LKPD dapat diamati dalam Gambar 1-3. 


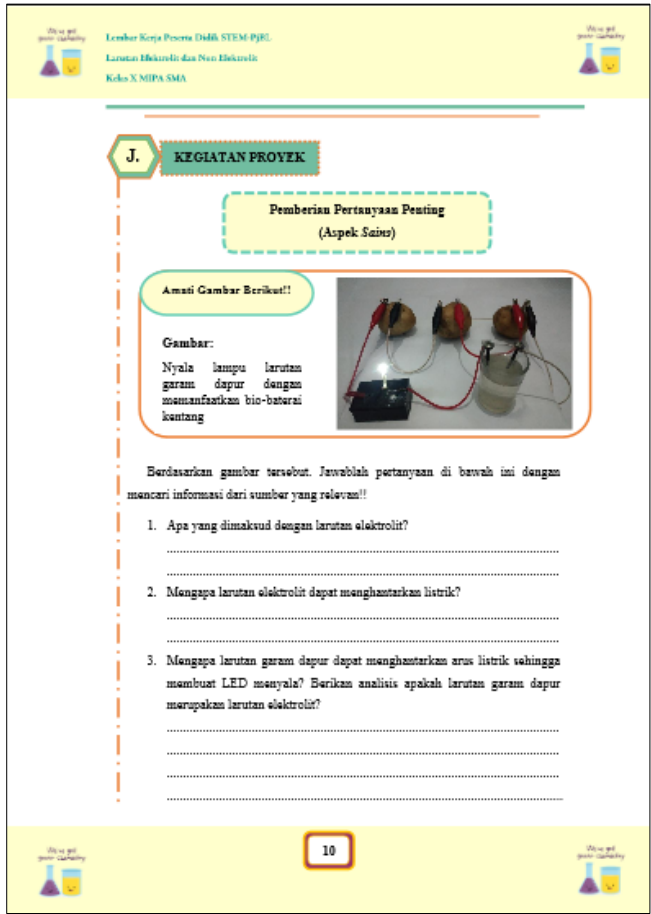

Gambar 1. Aspek science pada tahapan $\mathrm{PjBL}$ (pemberian pertanyaan penting)

Gambar 1 menunjukkan aspek science yang dipadukan dengan tahapan PjBL berupa pemberian pertanyaan penting, yang diilustrasikan melalui pengujian nyala lampu dengan diberikan beberapa pertanyaan mengenai larutan elektrolit dan non elektrolit sehingga LKPD tersebut diharapkan dapat memudahkan peserta didik untuk menguasai materi serta memperbanyak ilmu pengetahuan tentang larutan elektrolit dan non elektrolit melalui ilustrasi gambar serta perntanyaanpertanyaan yang diberikan dalam LKPD.

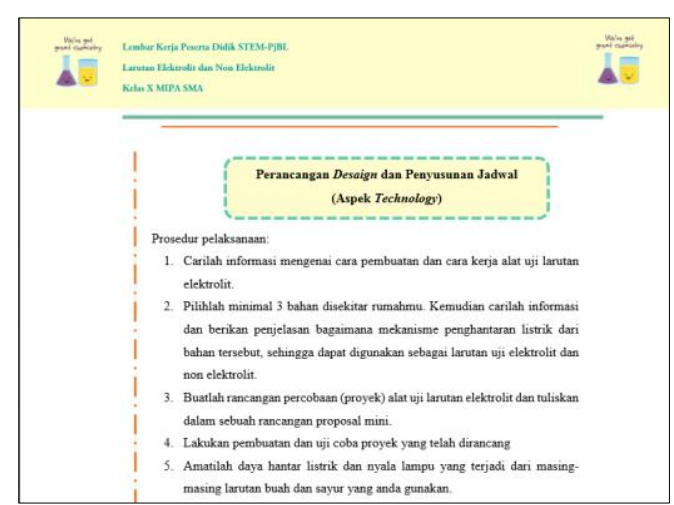

Gambar 2. Aspek technology pada tahapan PjBL (perancangan dan penyusunan jadwal)

Aspek technology dalam LKPD ini dipadukan dengan tahapan PjBL (perancangan proyek) yang berupa pemberian tugas kepada peserta didik untuk merangcang suatu proyek dengan memanfaatkan bahan-bahan sekitar sebagai alternatif larutan uji coba elektrolit.

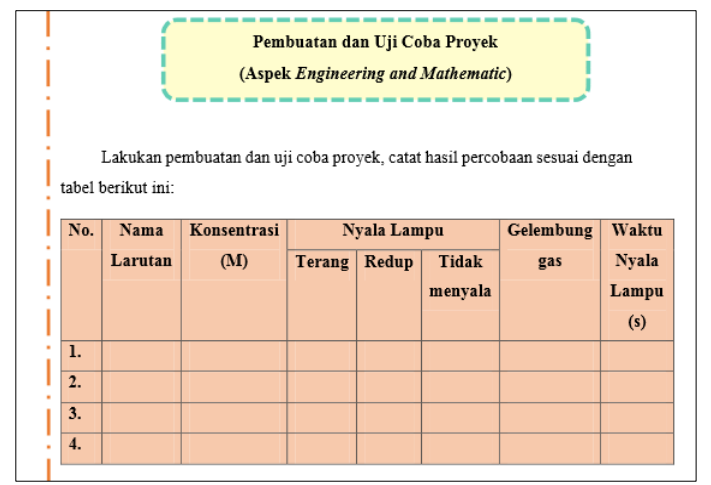

(A)

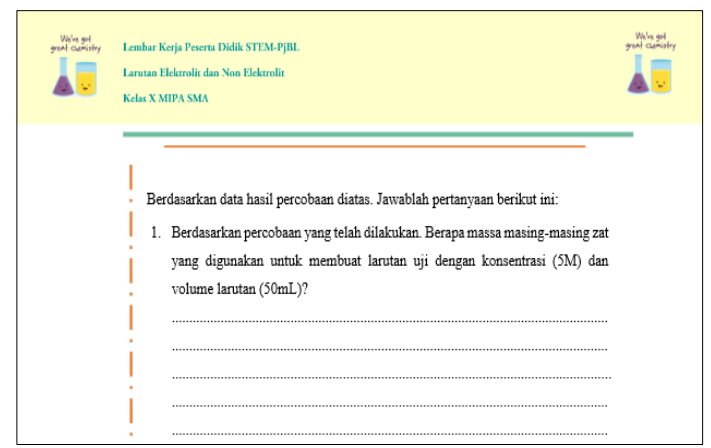

(B)

Gambar 3. Aspek engineering (A) dan mathematic (B) pada tahapan PjBL (pembuatan dan uji coba proyek)

Aspek engineering yang ditunjukkan dalam LKPD ini berupa perintah penugasan membuat alat uji elektrolit yang telah dirancang sebelumnya dan melakukan uji coba hasil proyek menggunakan larutan uji yang telah ditentukan sehingga diperoleh hasil uji coba yang dapat dituliskan dalam tabel yang telah disediakan dalam LKPD seperti pada Gambar 3 bagian (A). Aspek mathematic ditunjukkan pada Gambar 3 bagian (B) yaitu menghitung jumlah konsentrasi yang dibutuhkan dalam uji coba larutan elektrolit. 


\section{Tahap Develop (Pengembangan)}

Tahap ketiga yaitu tahapan pengembangan. Tahapan pengembangan dilakukan dengan tujuan untuk menciptakan LKPD berorientasi STEM dengan model PjBL materi larutan elektrolit dan non elektrolit dengan memanfaatkan bahan sekitar yang telah melalui proses revisi berdasarkan saran serta masukan yang disampaikan oleh penelaah serta tiga validator. Penelaah dalam penelitian ini adalah dosen pembimbing skripsi. Validator dalam penelitian ini adalah dua orang dosen pendidikan kimia UNESA serta satu orang guru kimia SMA Negeri 1 Gedangan Sidoarjo. Draft LKPD yang telah direvisi kemudian dilakukan uji coba terbatas kepada 9 orang peserta didik di kelas $\mathrm{X}$ MIPA 5 SMA Negeri 1 Gedangan Sidoarjo dengan pemilihan random sampling selama 3 kali pertemuan. Hasil revisi dalam pengembangan penenilitian ini diantaranya pada contoh desain cover yang menggambarkan isi dari LKPD yang dikembangkan, ilustrasi gambar pada tahapan pemberian pertanyaan penting. Bagian-bagian yang direvisi tersebut dapat ditunjukkan pada Gambar 4 dan 5 berikut.

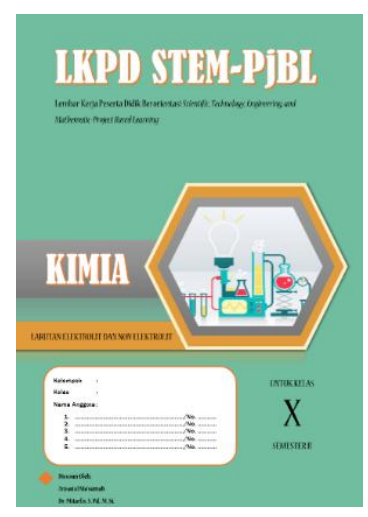

(A)

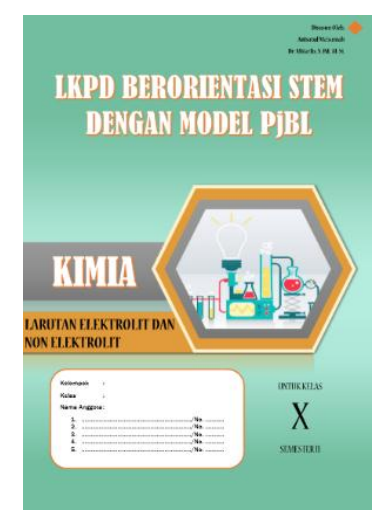

(B)
Gambar 4. Desain cover sebelum (A) dan sesudah revisi (B)

Desain cover sebelum revisi memiliki warna dasar yang cenderung lebih gelap serta ukuran dan tata letak huruf kurang sesuai, berdasarkan saran dari penelaah sehingga dilakukan revisi dan diihasilkan desain cover dengan degradasi warna serta penyesuaian ukuran dan tata letak huruf.

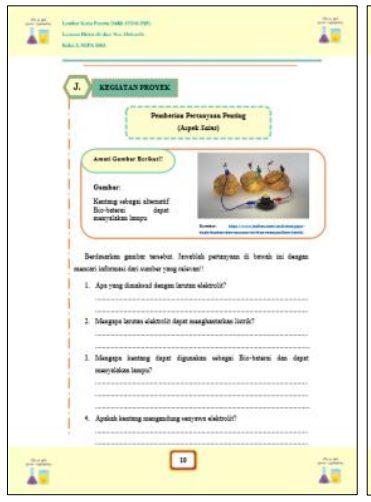

(A)

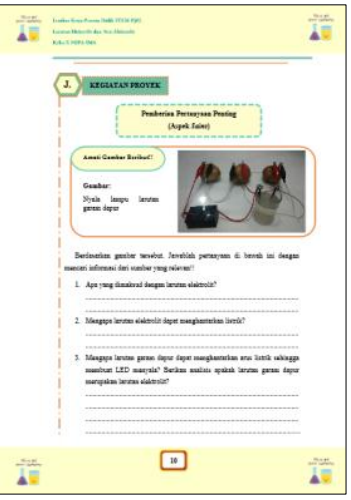

(B)
Gambar 5. Ilustrasi pada aspek science sebelum (A) dan setelah revisi (B)

Gambar 5 menunjukkan aspek science yang dipadukan dengan tahapan $\mathrm{PjBL}$ berupa pemberian pertanyaan penting yang diilustrasikan melalui pengujian nyala lampu sehingga melalui LKPD tersebut diharapkan mampu membantu peserta didik memahami materi serta meningkatkan ilmu pengetahuan tentang larutan elektrolit dan non elektrolit melalui ilustrasi gambar serta perntanyaanpertanyaan yang diberikan dalam LKPD.

Ilustrasi gambar pada aspek science sebelum revisi merupakan gambar dari biobaterai kentang tanpa ada penambahan larutan uji sedangkan setelah revisi merupakan gambar pengujian nyala lampu larutan garam dapur dengan memanfaatkan bio-baterai kentang. Dalam hal ini dapat dilihat bahwa gambar tersebut telah menggambarkan materi larutan elektrolit dan non elektrolit dengan memanfaatkan bahan sekitar.

\section{Kevalidan}

Kevalidan dalam pengembangan LKPD ini ditinjau dari validitas isi serta validitas konstruk untuk mengetahui kelayakan LKPD sehingga layak digunakan untuk membantu pembelajaran kimia yang baik. Hasil validitas isi dan konstruk dapat diamati dalam Gambar 6. 


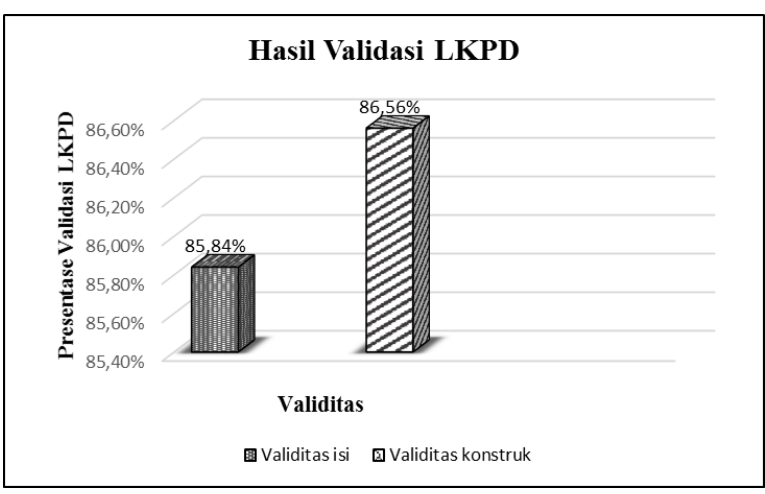

Gambar 6. Diagram Hasil Validasi LKPD

Komponen pada validitas isi berisi tentang kesesuai materi yang disajikan dalam LKPD. Kesesuaian materi dengan KI, KD, serta IPK yang disajikan dalam LKPD. Kesesuaian kegiatan proyek yang disajikan dalam LKPD. Kesesuaian aspek STEM yang disajikan dalam LKPD serta kesesuai fakta dan konsep dengan materi yang disajikan dalam LKPD. Berdasarkan hasil validasi diperoleh $85,84 \%$ menunjukkan kategori sangat valid, sehingga LKPD yang digunakan dapat digunakan dalam membantu proses pelaksanaan pembelajaran dengan baik. Melalui kegiatan-kegiatan dalam LKPD tersebut peserta didik dapat merancang serta membuat proyek nyata dalam kehidupan sehari-hari dengan berorientasi terhadap aspek Science, technology, engineering, and mathematic (STEM). Permasalahan pada dunia nyata merupakan komponen yang sangat penting dalam pembelajaran STEM terintregasi. Pembelajaran akan lebih bermakna ketika peserta didik dapat menciptakan hubungan antara pengetahuan sebelumnya dengan pengalaman serta keterampilan baru dalam konteks dunia nyata (Roehrig, dkk., 2021). Na'imah, dkk., (2015) juga menyebutkan hasil penetitiannya model pembelajaran PjBL berpotensi dalam memberikan peserta didik pengalaman kreativitas serta penerapan dalam kehidupan nyata.

Hasil validasi Konstruk dihasilkan rata-rata $86,56 \%$ dengan kategori sangat praktis. Validitas konstruk terdiri dari beberapa kriteria, yaitu kriteria penyajian, kriteria kebahasaan, dan kriteria kegrafikan. Hasil dari masing-masing kriteria validasi konstruk dapat diamati dalam Gambar 7.

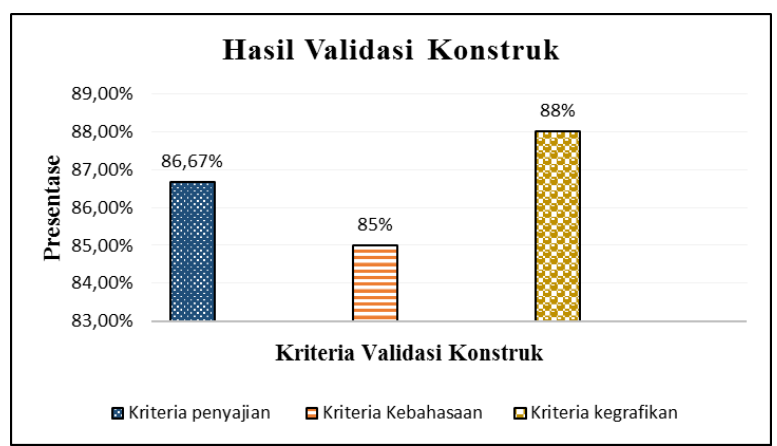

Gambar 7. Diagram Hasil Validasi Konstruk

Gambar 7 menunjukkan validitas konstruk terdiri dari beberapa kriteria yaitu kriteria penyajian dengan dihasilkan validasi sebesar 86,7\% menunjukkan kategori sangat valid, kriteria kebahasaan dihasilkan validasi sebesar 85\% menunjukkan kategori sangat valid, dan kriteria kegrafikan dihasilkan validasi sebesar $88 \%$ menunjukkan kategori sangat valid. Kriteria penyajian berisi tentang kelengkapan serta pendukung penyajian. Kriteria kebahasaan berisi tentang penggunaan bahasa yang baik dan benar. Kriteria kegrafikan berisi tentang kesesuaian desain, ilustrasi gambar, tata letak teks, dan penggunaan warna yang diaplikasikan dalam LKPD yang dikembangkan.

HasiI validasi LKPD pada penelitian ini diperkuat dengan hasil penelitian sebelumnya yang dilakukan oleh Syafe'i \& Effendi (2020) menunjukkan hasil pengembangan LKPD terintegrasi STEMPjBL pada materi termokimia dengan menerapkan model pengembangan 4-D dihasilkan LKPD dengan kategori valid serta praktis sehingga layak diterapkan dalam menunjang kegiatan pembelajaran yang baik.

\section{Kepraktisan}

Kepraktisan dalam pengembangan LKPD ini ditinjau dari aktivitas dan respon peserta didik mengenai LKPD yang dikembangkan. Aktivitas peserta didik dalam penelitian ini didasarkan pada tahapan model PjBL dengan berorientasi scientific, technology, engineering, and mathematics (STEM). Berdasarkan penelitian Mitarlis, dkk., (2017) dijelaskan tahapan PjBL yaitu memulai dengan pertanyaan essensial, merancang dan membuat desain proyek, menyusun jadwal, membuat proyek nyata 
dengan pengawasan guru, menyusun laporan dan mempresentasikan produk, mengevaluasi serta merefleksi produk. Proses penelitian ini menggunakan tahapan PjBL berorientasi STEM dilakukan daIam 3 kali pertemuan. Hasil observasi aktivitas yang didapatkan dari uji coba LKPD yang dikembangkan dapat dilihat dalam Gambar 8.

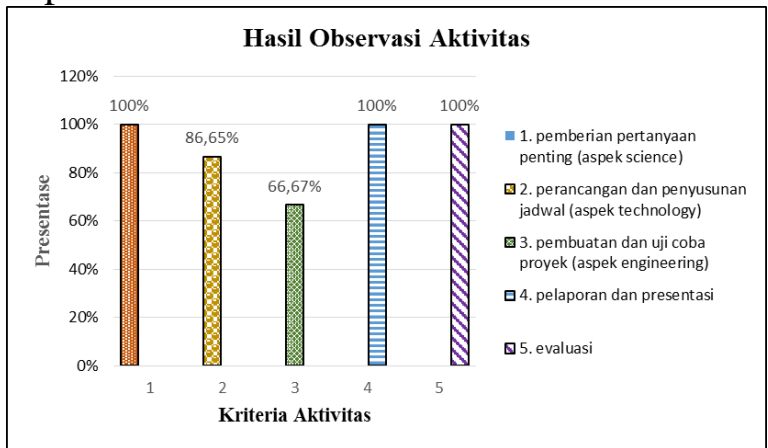

Gambar 8. Diagram Hasil Observasi Aktivitas

Observasi aktivitas pada Gambar 8 menunjukkan pertemuan pertama dimasukkan dalam kategori pemberian pertanyaan penting (aspek science) dengan perolehan presentase aktivitas sebesar $100 \%$ dengan kategori sangat praktis, perancangan dan penyusunan jadwal (Technology) diperoleh presentase aktivitas $86,65 \%$ dengan kategori sangat praktis pada pertemuan kedua dimasukkan dalam kategori pembuatan dan uji coba proyek (aspek engineering) diperoleh presentase sebesar $66,67 \%$ dengan kategori praktis. Pertemua ketiga dimasukkan dalam kategori pelaporan dan presentasi hasil proyek diperoleh presentase aktivitas $100 \%$ dengan kategori sangat praktis dan tahapan evaluasi diperoleh presentase aktivitas $100 \%$ dengan kategori sangat praktis. Berdasarkan dari hasil observasi aktivitas pembelajaran yang dilakukan saat uji coba kelompok kecil, dapat dilihat rata-rata dari tiga pertemuan tersebut yaitu sebesar $90,65 \%$ dengan kategori sangat praktis. Hasil tersebut dapat menjelaskan bahwa LKPD yang telah dikembangkan menggunakan model pembelajaran PjBL berorientasi STEM layak digunakan sebagai penunjang proses pembelajaran yang baik. Proses pembelajaran berdasar proyek dapat menciptakan pembelajaran yang lebih bermakna. Hasil aktivitas ini diperkuat dengan penelitian yang dilakukan Zahro (2021) menunjukkan hasil observasi aktivitas peserta didik dalam pembelajaran dengan menerapkan LPKD model PjBL dapat dikategorikan sangat praktis dengan diperoleh rata-rata $92,74 \%$ dalam 3 kali pertemuan. Na'imah, dkk., (2015) dalam penelitian juga menunjukkan bahwa diperoleh aktivitas belajar peserta didik dengan katergori aktif dan sangat aktif dengan pembelajaran PjBL.

Hasil aktivitas uji coba LKPD yang dikembangkan menunjukkan aktivitas yang paling rendah yaitu pada tahapan pembuatan dan uji coba proyek yaitu sebesar 66,67\% dengan kategori praktis. Hal tersebut dikarenakan pada pembelajaran berbasis proyek dengan metode daring ini peserta didik membagi pekerjaan dengan kelompok masing-masing, sehingga terdapat beberapa peserta didik yang melakukan praktikum, mencatat hasil percobaan, serta menyiapkan pelaporan hasil. Peserta didik yang lain tetap memperhatikan proses pembuatan serta uji coba proyek melalui google meet sehingga sama-sama mengetahui hasil dari pembuatan dan uji coba proyek yang telah dirancang. Aktivitas yang telah diamati dalam penelitian ini juga didukung dengan penelitian Astuti, dkk., (2019) menunjukkan peserta didik dapat menyelesaikan proyek yang telah dirangcang sesuai waktu yang telah ditentukan.

Angket respon peserta didik disebarkan kepada 9 orang peserta didik yang telah melakukan uji coba pembelajaran menggunakan LKPD berorientasi STEM dengan model PjBL dengan memanfaatkan bahan sekitar. Angket respon terdiri dari 12 pertanyaan dengan 2 diantaranya merupakan pertanyaan negatif dan 10 pertanyaan positif. Hasil angket respon peserta didik dikelompokkan dalam kriteria isi, kebahasaan, kegrafikan, dan kriteria pelaksanaan. Hasil angket respon peserta didik dapat diamati dalam Gambar 9. 


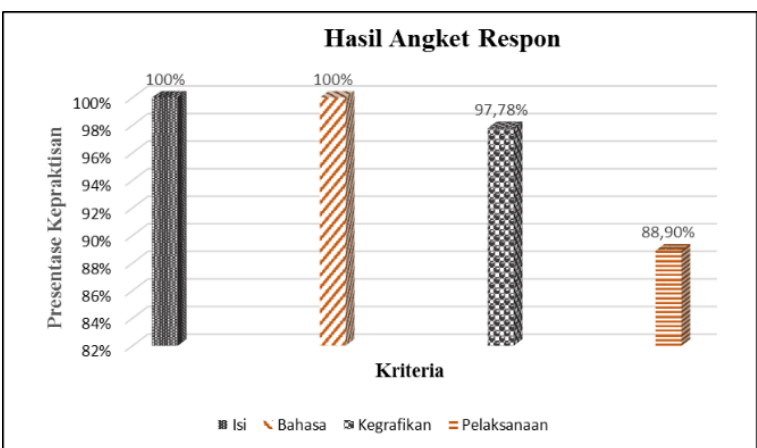

Gambar 9. Diagram Hasil Angket Respon

Gambar 9 berupa hasil respon dari peserta didik terhadap LKPD berorientasi STEM dengan model PjBL dengan memanfaatkan bahan sekitar, menunjukkan hasil $100 \%$ pada kriteria isi, $100 \%$ pada kriteria kebahasaan $97,78 \%$ pada kriteria kegrafikan, dan $88,9 \%$ pada kriteria pelaksanaan. Angket respon peserta didik diperoleh hasil rata-rata $96,67 \%$ menunjukkan kategori sangat praktis. Kriteria isi menunjunkan respon peserta didik terhadap kesesuaian isi LKPD. Kriteria kebahasaan menunjukkan respon peserta didik terhadap kemudahan bahasa yang digunakan dalam LKPD. Kriteria kegrafikan menunjukkan respon peserta didik terhadap desain, ilustrasi gambar, tata letak teks, dan penggunaan warna yang digunakan dalam LKPD. Kriteria pelaksanaan menunjukkan respon peserta didik terhadap pelaksanaan kegiatan pembelajaran dengan menggunakan LKPD yang telah dikembangkan. Respon tersebut menunjukkan bahwa LKPD berorientasi STEM dengan model PjBL memperoleh kategori sangat praktis sehingga dapat digunakan untuk menunjang proses pembelajaran yang baik.

Hasil data observasi aktivitas dan respon peserta didik dapat diketahui bahwa LKPD berorientasi STEM dengan model PjBL materi larutan elektrolit dan non elektrolit dengan menggunakan bahan sekitar dinyatakan sangat praktis serta layak digunakan untuk membantu berlangsungnya kegiatan pembelajaran kimia yang baik. Hasil penelitian ini diperkuat dengan penelitian dari Syafe'i \& Effendi (2020) menunjukkan hasil pengembangan LKPD terintegrasi STEM-PjBL pada materi termokimia dengan menerapkan modeI pengembangan 4-D diperoleh LKPD menunjukkan kategori valid serta praktis sehingga layak diterapkan dalam menunjang kegiatan pembelajaran yang baik.

\section{Keefektifan}

Keefektifan pada pengembangan LKPD yang dikembangkan didasarkan pada hasil belajar peserta didik yang meningkat, dilihat melalui pre test dan post test. Pre test dilakukan untuk melihat pengetahuan yang dimiliki peserta didik sebelum diterapkan uji coba LKPD. Post test dilakukan untuk melihat pengetahuan yang dimiliki peserta didik setelah diterapkan uji coba LKPD yang dikembangkan. HasiI pre test dan post test dari uji coba pada 9 peserta didik dapat diamati dalam Gambar 10 berikut.

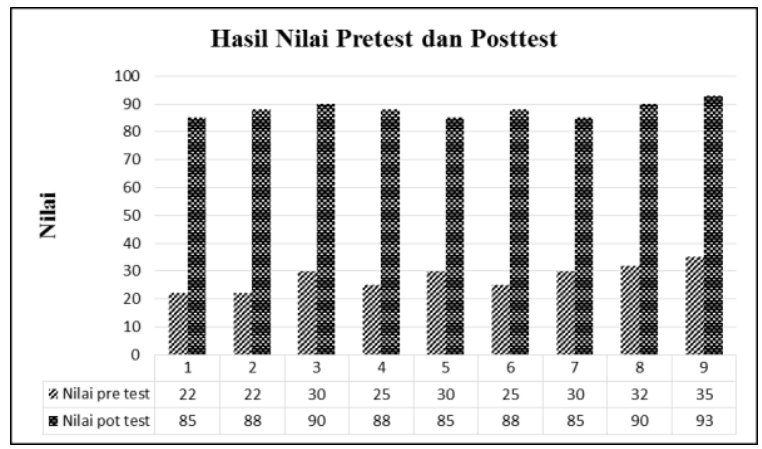

Gambar 10. Diagram Hasil Nilai Pretest dan Posttest

NiIai pretest dan post test pada Gambar 10 menunjukkan bahwa hasil belajar dari peserta didik menunjukkan peningkatan. Peserta didik memperoleh nilai yang tergolong rendah di bawah KKM sebelum dilakukan pembelajaran dengan menerapkan LKPD yang telah dikembangkan. NiIai peserta didik cenderung naik setelah dilakukan pembelajaran menggunakan LKPD yang dikembangkan. Pre test dan post test selanjutnya dihitung dengan rumus $n$-gain score dan diperoleh hasil rata-rata $n$-gain score 0,83 menunjukkan kategori tinggi.

Hasil penelitian ini menunjukkan setelah penggunaan LKPD berorientasi STEM dengan model PjBL materi larutan elektrolit dan non elektrolit dengan memanfaatkan bahan sekitar, pemahaman konsep peserta didik pada materi larutan elektrolit dan non elektrolit cenderung lebih tinggi sehingga peserta didik memiliki hasil 
belajar yang meningkat dan tergolong tinggi. Penelitian ini membuktikan bahwa penggunaan LKPD berorientasi STEM dengan model PjBL dengan memanfaatkan bahan sekitar pada materi larutan elektrolit dan non elektrolit dapat dikatakan efektiv untuk mendukung proses pembelajaran yang baik. Uji coba LKPD ini, peserta didik dilatihkan untuk beIajar dengan mementingkan aspek STEM dalam kegiatan proyek nyata pada kehidupan sehari-hari sehingga menciptakan pembelajaran yang lebih bermakna dan dapat meningkatkan pemahaman konsep peserta didik terhadap materi larutan elektroIit dan non elektrolit. Penelitian ini sesuai dengan penelitian Sumarni, dkk., (2019) menyatakan hasil dalam penelitianya bahwa siswa dapat mencapai kemampuan kognitif dengan kategori baik dan pada indikator pemahaman konsep mencapai kriteria tertinggi, pembelajaran yang mengaitkan keempat aspek STEM jika diintregasikan dengan pembelajaran berpendekatan saintifik dapat melatih siswa untuk mendapatkan kemampuan kognitif yang baik. Hasil penelitian ini juga diperkuat dengan penelitian terdahulu bahwa pembelajaran dengan menerapkan model $\mathrm{PjBL}$ berbasis STEM dapat menunjukkan peningkatan kemampuan berfikir analisis serta penguasaan konsep peserta didik (Syafe'i \& Effendi, 2020). Penelitian Rahman, dkk., (2019). Menunjukkan bahwa penerapan model PjBL berbasis STEAM dapat menunjukkan hasil belajar yang meningkat, pada periode pertama dengan hasil belajar kategori rendah menjadi kategori tinggi pada hasil belajar periode kedua.

\section{DISKUSI}

Penelitian ini telah menghasilkan LKPD berorientasi STEM dengan model PjBL materi larutan elektrolit non elektrolit dengan memanfaatkan bahan sekitar yang telah melalui tahapan pendefinisian, perancangan, serta pengembangan.

LKPD berorientasi STEM dengan model PjBL materi larutan elektrolit non elektrolit dengan memanfaatkan bahan sekitar dapat dikatakan sangat valid dan layak untuk mendukung proses pembelajaran kimia yang baik, dilihat dari hasil penilaian validator terhadap LKPD yang dikembangkan sehingga menghasilkan nilai sangat valid pada kriteria validasi isi dan kriteria validasi konstruk.

LKPD berorientasi STEM dengan model PjBL materi larutan elektrolit dan non elektrolit dengan menggunakan bahan sekitar dinyatakan sangat praktis serta layak digunakan untuk membantu berlangsungnya kegiatan pembelajaran kimia yang baik, dilihat dari hasil observasi aktivitas serta respon peserta didik saat pembelajaran yang menunjukkan hasil sangat praktis.

LKPD berorientasi STEM dengan model PjBL dengan memanfaatkan bahan sekitar pada materi larutan elektrolit dan non elektrolit dapat dikatakan efektiv untuk mendukung proses pembelajaran yang baik karena pemahaman konsep peserta didik pada materi larutan elektrolit dan non elektrolit cenderung lebih tinggi sehingga peserta didik memiliki hasil belajar yang meningkat.

\section{KESIMPULAN}

Berdasarkan penelitian yang telah dilakukan dapat disimpulkan bahwa dihasilkan LKPD berorientasi STEM dengan model PjBL materi larutan elektrolit non elektrolit dengan memanfaatkan bahan sekitar, yang layak digunakan dalam membantu proses pembelajaran kimia yang baik. Penelitian ini menunjukkan hasil validitas LKPD pada kriteria isi $85,84 \%$ dan validitas konstruk $86,56 \%$ menunjukkan kategori sangat valid. Hasil respon peserta didik terhadap LKPD yang dikembangkan diperoleh presentase 96,67\% menunjukkan kriteria sangat praktis, observasi aktivitas pada 3 kali pertemuan dihasilkan rata-rata presentase $90,65 \%$ menunjukkan kategori sangat praktis. Hasil keefektivan LKPD diperoleh rata-rata $N$ - 
Gain score 0,83 menunjukkan kategori tinggi, membuktikan hasil belajar peserta didik mengalami peningkatan dalam tes sebelum dan sesudah pembelajaran menggunakan LKPD yang dikembangkan.

\section{DAFTAR PUSTAKA}

Astuti, I. D., Toto, T., \& Yulisma, L. (2019). Model Project Based Learning (PjBL) Terintegrasi STEM untuk Meningkatkan Penguasaan Konsep dan Aktivitas Belajar Siswa. Jurnal Pendidikan dan Biologi, 11(2), 93-98. https://doi.org/10.25134/quagga.v11i2.1 915

Chiang, C. L., \& Lee, H. (2016). The Effect of Project-Based Learning on Learning Motivation and Problem-Solving Ability of Vocational High School Students. International Journal of Information and Education Technology, 6(9), 709712.

https://doi.org/10.7763/IJIET.2016.V6.7 79

Farida, I., Sunarya, R. R., Aisyah, R., \& Helsy, I. (2020). Pembelajaran Kimia Sistem Daring di Masa Pandemi Covid19 Bagi Generasi Z. Karya Tulis Ilmiah (KTI) Masa Work From Home (WFH) Covid-19. UIN Sunan Gunung Djati Bandung Tahun, 1-11.

Ibrahim, \& Wahyusukartingsih. (2014). Model Pembelajaran Inovatif Melalui Pemaknaan. Surabaya: UNESA University Press.

Jauhariyah, F. R., Suwono, H., \& Ibrohim. (2017). Scientific, Thecnology, Engineering, and Mathematics Project Based Learing (STEM-PjBL) pada Pembelajaran Sains. Prosiding Seminar Pendidikan IPA UM, 2, 432-436.

Kemendikbud. (2019). Laporan Hasil UN 2019 Capaian Nasional. Pusat Penelitian Pendidikan. https://hasilun.puspendik.kemendikbud. go.id
Larson, L., \& Miller, T. (2011). 21st Century Skills: Prepare Students for the Future. Kappa Delta Pi Record, 47, 121-123. https://doi.org/10.1080/00228958.2011. 10516575

SKB Empat Menteri. (2020). Keputusan Bersama Menteri Pendidikan dan Kebudayaan, Menteri Agama, Menteri Kesehatan, dan Menteri Dalam Negeri Republik Indonesia Nomor 01/KB/2020, Nomor 516 Tahun 2020, Nomor HK.03.01/Menkes/363/2020, Nomor 440-882 Tahun 2020. Panduan Penyelenggaraan Pembelajaran Pada Tahun Ajaran 2020/2021 dan Tahun Akademik 2020/2021 di Masa Pandemi Coronavirus Disease 2019 (COVID-19). https://covid19.go.id/p/regulasi/skbpembelajaran-tahun-ajaran-baru-dimasa-pandemi-covid-19.

Mitarlis, Yonata, B., \& Hidayah, R. (2017). Implementation of Science Character Values with Green Chemistry Insight Integrated on Basic Chemistry Course by Using Project Based Learning. Advanced Science Letters, 23, 1194311947.

https://doi.org/10.1166/asl.2017.10549

Na'imah, N. J., Supartono, \& Wardani, S. (2015). Penerapan Pembelajaran Berbasis Proyek Berbantuan ELearning. Jurnal Inovasi Pendidikan Kimia, 9(2), 1566-1574.

Nani, K. La, \& Kusumah, Y. S. (2015). The Effectivenes Ofict-Assisted ProjectBased Learning in Enhancing Student Statistical Communication Ability. International Journal of Education and Research, 3(8), 187-196.

OECD. (2018). Indonesia What 15-year-old students in Indonesia know and can do Figure 1. Snapshot of performance in reading, mathematics and science. Program for internasional Student Assesmen (PISA), 1-10. 
Permendikbud, N. 36. (2018). Permendikbud Nomor 36. Tentang perubahan Permendikbud Nomor 59 Tahun 2014. jdih.kemendikbud.go.id

Prastowo, A. (2011). Panduan Kreatif Membuat Bahan Ajar Inovatif: Menciptakan Metode Pembelajaran Yang Menarik dan Menyenangkan. Yogyakarta: Diva Press.

Rahman, M. K., Suharto, B., \& Iriani, R. (2019). Meningkatkan Berfikir Kreatif dan Hasil Belajar Menggunakan Model PjBL Berbasis STEAM Pada Materi Larutan Elektrolit dan Nonelektrolit Improving Creative Thinking And Learning Results Using Steam-Based Pjbl Models In The Study Of Electrolyte And Non-Elect. Journal of Chemistry And Education, 3(1), 10-22.

Riduwan. (2016). Skala Pengukuran Variabel-variabel Penelitian. Bandung: Alfabeta.

Roehrig, G. H., Dare, E. A., Ring-Whalen, E., \& Wieselmann, J. R. (2021). Understanding coherence and integration in integrated STEM curriculum. International Journal of STEM Education, 8(1), 1-21. https://doi.org/10.1186/s40594-02000259-8

Sugiyarti, L., Arif, A., \& Jakarta, U. N. (2018). Pembelajaran abad 21 di sd. Prosiding Seminar dan DiskusiNasional Pendidikan Dasar, 439-444.

Sumarni, W., Wijayati, N., \& Supanti, S. (2019). Melalui Pembelajaran Berbasis Proyek. Jurnal Pembelajaran Kimia Universitas Negeri Malang, 4(1), 1830.

Syafe'i, S, \& Effendi. (2020). Pengembangan LKPD Terintegrasi STEM-PjBL (Project Based Learning ) pada Materi Termokimia. EduChemia (Jurnal Kimia dan Pendidikan), 2(2), 85-90. https://doi.org/https://doi.org/10.24036/e

$$
\text { kj.v2.i2.a124 }
$$

Wijaya, E. Y., Sudjimat, D. A., Nyoto, A., \& Malang, U. N. (2016). Transformasi Pendidikan Abad 21 sebagai Tuntutan Pengembangan Sumber Daya Manusia di Era Global. Prosiding Seminar Nasional Pendidikan Matematika Universitas Kanjuruhan Malang, 1, 263-278.

Zahro, B. L. (2021). Student Worksheet Oriented on Project Basen Learning to To Student Creative Thingking Skills on Acid-Base Material. UNESA Journal of Chemical Education, 10(1), 1-10. 